\title{
The Relationship between Corporate Social Responsibility Reporting and Firm Performance and the Moderating Role of Firm Life Cycle Stages: Evidence from China
}

\author{
Naveed Jan ${ }^{1}\left(\mathbb{D}\right.$, Arodh Lal Karn ${ }^{2, *}$, Zeyun $\mathrm{Li}^{3}{ }^{\circledR}$ and Xiyu Liu ${ }^{1}$ (D) \\ 1 Department of Management Science, Shandong Normal University, Jinan 250000, China; \\ needo@yahoo.com (N.J.); xyliu@sdnu.edu.cn (X.L.) \\ 2 School of Management, Northwestern Polytechnical University, Xi'an 710072, China \\ 3 School of Humanity, Universiti Sains Malaysia, Gelugor 11800, Malaysia; Lizeyun@yahoo.com \\ * Correspondence: alkmaithili@nwpu.edu.cn
}

Citation: Jan, N.; Karn, A.L.; Li, Z.; Liu, $X$. The Relationship between Corporate Social Responsibility Reporting and Firm Performance and the Moderating Role of Firm Life Cycle Stages: Evidence from China. Sustainability 2021, 13, 10038. https:// doi.org/10.3390/su131810038

Academic Editor: Roberta Costa

Received: 6 August 2021

Accepted: 2 September 2021

Published: 8 September 2021

Publisher's Note: MDPI stays neutral with regard to jurisdictional claims in published maps and institutional affiliations.

Copyright: () 2021 by the authors. Licensee MDPI, Basel, Switzerland. This article is an open access article distributed under the terms and conditions of the Creative Commons Attribution (CC BY) license (https:// creativecommons.org/licenses/by/ $4.0 /)$.

\begin{abstract}
This study aims to investigate the relationship of firm performance and corporate social responsibility reporting and the moderating role of a firm's life cycle stages in Chinese listed companies. We used the sample of all A-share listed firms on the Shanghai and Shenzhen stock exchanges for the period 2010 to 2020. The authors used pooled ordinary least squares (OLS) regression as a baseline methodology. Our regression results show that positive Corporate social responsibility (CSR) activity significantly reduces the performance of the firm. In addition, the negative link between positive Corporate social responsibility and a firm's performance is more pronounced for firms in mature life cycle stages. Our results are robust to alternative proxy measures of ROA for firm performance, corporate social responsibility reporting, and life cycle stages. To control the possible problem of endogeneity, we use a one-year lag and 2SLS least squares regression. We find that firm performance has a statistically significant influence on CSR reporting. Moreover, we see that firms with high performance are more likely to report CSR activities than low-performance firms. Additionally, six out of ten control variables (Independent Director, Board Shares, State Owned Enterprise, Board Meeting, Chief executive officer Duality, and Firm Growth) have positive influences on CSR reporting. These findings hold for a set of robustness tests. Our results have implications for the development of CSR reporting in developing countries such as China. Our research suggests that, in China, firms with better financial performance undertake more CSR reporting. This paper contributes to the existing literature by investigating the effect of firm performance on CSR reporting and the moderating role of a firm's life cycle stages in Chinese listed companies. Additionally, this paper enriches the current literature on CSR reporting and highlights the importance of a firm's financial performance for better environmental performance and reporting.
\end{abstract}

Keywords: corporate social responsibility reporting (CSRR); firm performance (FP); corporate life cycle stages (FLCS); stakeholder theory (ST); life cycle theory (LCT); legitimacy theory (LT); China (C)

\section{Introduction}

Debate on the paradoxical nature of corporate social responsibility (CSR) is at its full swing in media, in academia, and amongst practitioners, and in last couple of decades, several researchers conducted research on CSR from various aspects [1-7]. The question of whether practicing CSR has a significant added value to the performance of firms has yet to find the right answer. This question possesses valuable implications for solutionseeking managers while making CSR-linked decisions [8]. Though the common theme in all research conducted in the past is a link between CSR and firm financial outcome [9,10], a lot of studies have been conducted to prove or disapprove the link between CSR reporting and firm performance. In these studies, many researchers claimed to find a connection between CSR reporting and firm's output $[11,12]$ but the method in which CSR impacts the 
output of firms is still debated. These polarizing views amongst researchers on the nature of the link between CSR and the output of firms have contradictory perspectives. Some academics believe that CSR reporting is positively related to firm performance [13-16] because the gain achieved is greater than the cost incurred in CSR activities conducted by firms though they are not sure about how and when this relations become positive. However, some economists from the neoclassical school of thought argued that CSR reporting have negative effects on a firm's financial outcome as they endorse that this social expense can be sidestepped [16-18]. The main objection is incurring additional costs due to CSR information-related practices. According to them, this unnecessary cost can be avoided and can be used for more productive purpose, which can benefit the firm in a better way. Besides proponents of positive and negative relations between the performance of a firm and CSR, there is also a third type of argument that denies the relationship between the performance of a firm and CSR reporting, and this relation is spurious or neutral [19].

We examined the influence of firm performance on corporate social responsibility (CSR) reporting through the lens of the life cycle theories, the stakeholder, and legitimacy theories, expanding on a previous study [20]. As we just discussed, prior research has speculated a positive, negative, or neutral link amid CSR reporting and firm financial performance [20]. This means that their link may be affected or triggered by some other variables [21]. Keeping this assumption in mind, it can be established that their relationship is indirect rather than direct. Some research has explored the link between CSR reporting and firm performance, which is mediated by some indirect variables. We found one study that examines the effect of firm maturity on corporate social responsibility reporting [21]. Therefore, we intend to study the impact on firm performance by CSR reporting while incorporating the moderating role of a firm's life cycle as a moderating variable. Additionally, a few studies have used a firm's life cycle as a moderator but not to assess CSR reporting and firm performance [21-23]. The construct of a firm's life cycle has been used in various studies in different perspectives [22-28]. This research is a unique effort to assess how CSR reporting affects firm performance with firm life cycle as a moderating variable. This important link has been ignored in previous researches. We shows how firm life cycle as a moderator between CSR reporting and firm performance is absent in research literature. Therefore, our intention is to fill this lacuna in the existing literature.

Recent research is different from existing researches in two aspects. First, we incorporate a new contribution while integrating the construct firm life cycle into CSR reporting research. This proves that firm life cycle models are noticeable methods of integrating CSR reporting research into a classic theoretical framework. This is a core advancement, which incorporates the gap between two types of organizations. Second, the more important is our addition to the body of knowledge while studying this combination of variables for the first time. Though the relationship between CSR reporting and a firm's financial performance have been studies with various moderating variables, the firm life cycle as a moderator in this context is a unique and, until now, has not been incorporated in any research. This is why we test to which level a firm's life cycle models contribute to the CSR reporting literature.

The upcoming topics of this paper are arranged in the following order. Section 2 is about the literature review and hypothesis development. Section 3 documents the variables and data. Section 4 of the document is the empirical part of this paper. At the end, in Section 5 , we discuss our conclusion along with the limitations and potential future research lacuna of our study.

\section{Literature Review and Hypothesis Development}

In the last couple of decades, few firms invested more in CSR reporting activities due to pressure from all stakeholders about investing more in CSR reporting-related activities as these stakeholders believed that investing more in CSR increases a firm's performance. Contradictorily, some executives from other firms resisted on the belief that investing more in CSR reporting does not improve firm performance. Moreover, they added that studies 
that claim a positive relation between CSR reporting and firm performances have some core theoretical as well as empirical flaws. Such a major flaw is the misspecification of models by omitting some valuable variables that are linked to the profitability of a firm [3]. Conclusively, prior research has vitally emphasized the potential positive, negative, or neutral link amid CSR reporting and firm financial performance [16-18]. This means that their link may be affected or triggered by some other variables [20]. Keeping this assumption in mind, it can be established that their relationship is indirect rather than direct. To fill this lacuna, this research makes a unique effort to assess the extent to which an indirect variable can a play moderating role amid CSR reporting and firm performance while incorporating a firm's life cycle as a moderating variable. This study uniquely underpins the moderating role of a firm's life cycle between corporate social responsibility and firm performance.

\subsection{Firm Performance and CSR Reporting}

Theory: Traditionally, the basic motivation behind companies to reduce agency cost and to increase stockholder wealth by acquiring maximum income due to the anticipations of shareholders [22]. Currently, organizations work worldwide, where they also similarly come to agreements with loan shark, customers, and dealers with various social and environmental rules. Thus, firms must satisfy the social and environmental rules, to satisfy the broader stakeholder anticipations. Stakeholder theory suggests that a longstanding company depends on the tendency of stakeholders and, in this manner, corporate social responsibility is increased to maintain corporate promises to the public and to the stakeholders [23]. We link the literature on the factors influencing corporate social responsibility and firm life cycle theory. We also demonstrate that when the life cycle influences a company's capability to invest in corporate social responsibility [24]. Life cycle theory posits that companies focus on methodical changes in functioning, spending and funding activities, financial grants, administrative abilities, possibility craving, and plans as they develop through various phases [25].

As per legitimacy theory, better performing companies are obligated to address public and social concern and to provide complete reports on CSR activities [26]. It is due to the accessibility of financial resources that companies assume additional CSR performance and CSRR. The supporters of legitimacy theory recognize corporate social responsibility information as being useful in managing the discernments of society concerning the social and environmental effects of corporate procedures [27]. However, current proof is varied Sebastian, Garriga [28-30] endorsing it as positive, [31] finding a negative association, Garriga, Inoue [30-32] not obtaining any remarkable link between firm performance and CSR reporting. These dissimilar consequences are possibly due to official and cultural changes amongst nations [33,34]. Chinese companies mainly consider financial reward when concluding the effects of reporting CSR activities due to an absence of controlled costs and pressure from stakeholders [35]. Thus, when a firm has a decent performance, this inspires and supports CSR reporting.

Bird [33], in the established market, producing the most important advantage for shareholders is a biggest concern, that is directly reciprocal of corporate performance. By applying the survey technique, Teoh [31], suggested that bosses also watch performance levels to monitor the level of CSR reporting. Nevertheless, this determination differs in the budget amongst settled and developing markets $[14,17,18]$. Hence, more studies are required to check this connection [28,31,32].

Teoh [31] examined the link between the reporting of CSR and firm performance. The sample involved 322 Fortune 500 firms, and the firm performance info from the ORBIT database and data related to CSR were composed from the KLD data list. The outcomes showed a positive and significant link between CSR with Tobin's $Q$ and return on assets (ROA). Nevertheless, return on equity (ROE) was not found to be significantly connected to CSRR. 
Wang, Basuony and $\mathrm{Lu}[14,17,18]$ examined the connection between firm performance and the corporate social responsibility information of listed companies in China in the year 2008. The sample data were from 1574 non-financial, registered firms from the China Stock Market and Accounting Research database. The CSR information was collected from the Blue book of Corporate Social Responsibility reporting in 2009. Return on assets (ROA) was used as a proxy for firm performance. The conclusions established that companies with a good ROA lead to better CSR performance. A positive firm performance (FP) and corporate social responsibility (CSR) connection suggests that CSR obligation provides systematic reports that meet the demand of stakeholders even if there is no considerable development in CSR obligation and performance (reputation worth and reciprocal customers). Ahmad, AL-Hadi and Kao [25,26,28], older firms with consistent performance contribute more to CSR activities in which there is a focus on environmental performance. Current study is the further extension of the study saeidi [19] considering a greater sample of Chinese firms and by covering a longer period, from 2010 to 2020. Based on the above conversation, we contend that a positive link between firm performance (FP) and corporate social responsibility reporting (CSRR) exists among Chinese companies.

Thus, the relation between CSRR and firm performance is possibly moderated by firm life cycle stages. Therefore, we hypothesize the following:

Hypothesis (H1a): The association between CSR reporting and Firm performance is positive.

Hypothesis (H1b): High performing firms have a positive effect on CSR reporting compared with low performing firms.

Hypothesis (H1c): Firm life cycle stages positively moderate the association between CSR reporting and firm performance.

\subsection{Moderating Role of Firm Life Cycle and CSR Reporting}

This is a unique study as firm life cycle stages are used as a moderator variable for first time. In this paper, we endorsed the construct firm life cycle (FLC) as a moderating variable affecting corporate social responsibility reporting (CSRR) and firm financial performance (FFP). As a moderating variable, firm life cycle (FLC) stages help us to compare new and old firms with a single theoretical model [32-34]. Different stages of firm life cycle comprise different set of factors, which affects the stages directly or indirectly and changes the effect of CSR reporting on firm performance. There is also a belief that maturity in firms changes the amount of time and investment in CSR. The reason for this is because old firms are comparatively more stable than new firms and have more predictable outcomes for cash inflows and outflows [20]. This view attracts more investments for older firms. However, opposite to this view is that old firms being stable is why they do not feel much need to invest in CSR to increase their wellbeing, which is already at desired level. In short, new firms have a marginal advantage in investing in CSR compared with older firms, which indicates that new firms are more suitable for investing in CSR than old firms [20]. However, young firms can face cash flow problems such as a bad liquidity ratio holding back young firms from competing with old firms while investing in CSR [21]. These firms may have to raise expensive capital while experiencing problems with uncertain future cash flows, and making a profit while arranging for additional capital is a hard job [13,14,22].

In early or lateral stages of life cycle, concerns such as engaging in CSR and its disclosure, indirect expenses such as goodwill shocks, and economic reporting impacts are less valuable to firms than capital to survive; innovation; consistent cash flows and growth in a given scenario, which are enticing for firms in their early stages of life; cost and risky investments with innovations [34]. The availability of resources and expertise, which are only possible at mature firms allows firms to focus on strengthening their investments and reputation [35]. Maturity also brings stronger financial ratios accompanied with consistent and higher dividends and cash inflows than young firms [36]. Moreover, Older firms are 
sensitive about important matters such as the reputation of the firm, and dealing with major stakeholders and regulatory departments of the government. Mature firms take CSR-related activities more seriously than firms in their early or late stages because of their interests being at stake [37].

As we documented above, various studies have claimed that the nature of the relationship between the performance of a firm and CSR reporting is not definite, and we also established that this relation is indirect rather than direct. This study also has focuses on identifying the role of a firm's life cycle as a moderator, separating it from other involved variables. Using firm life cycle as a moderator is only significant when other factors such as size and age do not have any moderating effect between firm performance and CSR reporting [38]. Whether it is the size or age of firm, these variables represent partial aspects of a firm, whereas a firm's life cycle represent almost all aspects of a firm. Based on this, the following hypothesis can be formulated:

Hypothesis (H2a): The connection between firm life cycle stages has a negative effect on CSR reporting.

Hypothesis (H2b): The link between CSR reporting firm performance is moderated by firm life cycle stages.

\section{Research Methodology}

\subsection{Sample}

To measure the connection between CSR reporting and firms performance in China, we collected data from Chinese A-share firms listed on the Shanghai and Shenzhen stock exchanges for the period from 2010 to 2020 for all variables. We compiled all of the data from the Chinese stock market and Accounting Research Database (CSMAR). After dropping the observations with missing data, our final sample was reduced to 11298 firm-year observations.

\subsection{Dependent Variable}

To test our hypotheses, we used CSR reporting as a dependent variable measured through reporting of CSR information issued by firms in their annual report. We collected the data from the CSMAR database to measure CSR disclosure. We developed the CSRR index using an amphibious method: 1 if detail was stated and 0 if not. The whole score of CSR disclosure has been calculated as the following CSR reporting index items and binary scale: (1) Referring to GRI Sustainability Reporting Guideline or Not 1.0; (2) Deficiencies of Company or Not 1.0; (3) Protection of Supplier Interests or Not 1.0; (4) Public Relations and Social \& Public Welfare or Not 1.0; (5) Protection of Creditor Interests or Not 1.0; (6) Secure Production or Not 1.0; (7) Protection of Interests of Clients and Consumers or Not 1.0; (8) Social Responsibility System Construction and Improvement or Not 1.0; (9) Protection of Shareholder Interests or Not 1.0; (10) Protection of Employee Interests or Not 1.0; and (11) Environment and Sustainability or Not 1.0. The score for corporate social responsibility reporting was computed based on the following formula: CSR_Scorei, $\mathrm{t}=\sum_{n}^{11}\left(\frac{i}{n}\right) \times 100$, where $i$ equals 1 if the item is described and 0 otherwise and where $n$ represents the number of items.

\subsection{Independent Variables}

Our study used, firm performance (PF) is the independent variable, measured by market-based Tobin's $Q[14,17,18]$. Thus, we measure Tobin's $Q$ as the market capitalization of total assets minus the equity book value minus deferred tax liability divided by the total assets.

\subsection{Moderating Variable}

We considered the firm life cycle stages (FLCS) as a moderating variable. There is little agreement in the literature on the suitable method for unique firm life cycle stages [30-32]. 
Particular to this and the actuality that various researcher suggest different numbers of firm life cycle stages [33] for a worthy analysis of this), we do not beginning with any belief as to exactly how many steps we must differentiate. An additional suggestion of the method in [35] is that steps are not supposed to be built in a deterministic development. Moderately, firms can withdraw from one step to another in agreement with the prevailing arrangements of variables. Furthermore, there is no anticipation that firms will use the same duration in each phase [36]. We argue for our arrangement method as follows. Initially, we recognized the main variables of our study that used in previous studies to configure FLCS with many dimensions. These contain three related variables: total assets growth, sales growth, and organization age [37].

\subsection{The Model}

To investigate the effect of CSR reporting on firm performance, we estimated Equation (1) and we use pooled ordinary least squares (OLS). To check the effect of firm life cycle stages on CSR reporting, we estimated Equation (2). To check the relation between CSRR and firm performance being possibly moderated by firm life cycle stage, we estimated Equation (3):

$$
\begin{gathered}
\text { CSRRit }=\beta 0+\beta 1 F P+\sum_{I=1}^{N} \beta C V i t+\varepsilon i t \\
\text { CSRRit }=\beta 0+\beta 2 F L C S+\sum_{I=1}^{N} \beta C V i t+\varepsilon i t \\
\text { CSRRit }=\beta 0+\beta 3 F P \times F L C S+\sum_{I=1}^{N} \beta C V i t+\varepsilon i t
\end{gathered}
$$

where CSRR refers to corporate social responsibility reporting, FP represents firm performance (TQ), and FLCS refer to a firm's life cycle stages. CVit refers to all control variables (board size, firm size, independent director, board share, BTMA, SOE, board meeting, financial leverage, CEO duality, and firm growth).

\subsection{Control Variables}

In this study, we added the following control variables: board size, firm size, number of independent directors, board share, BTMA, SEO, board meeting, financial leverage, CEO duality, and firm growth to further check the extent of their influence on CSR reporting quality [33]. Finally, we added industry dummies to control for the specific effect of industry, and we included year dummies that are used to control the potential effect of time. For more details, see Table 1.

\subsection{Descriptive Statistics and Correlation Analysis}

Table 2 presents descriptive statistics for all of the variables used in this analysis. The mean value of CSRR is 28.7, with a standard deviation 19.46. The average value of firm performance $(\mathrm{PF})$ is 2.45 , with a standard deviation of 1.94 . The mean value of firm life cycle stages is 2.017, with a standard deviation of 0.88 . The average values of board size (BS), firm size (FS), independent director (ID), board shareholders (BSH), BTMA, SOE, board meeting (BM), and financial leverage (FL), CEO duality (CD), and firm growth (FG) are 9.48, 23.19, $3.49,19.95,1.18,0.16,10.21,0.50,0.15$, and 13.83, respectively. Here, Table 2 represents the Pearson correlation analysis. A correlation analysis is used to check the presence of multicollinearity by testing the correlation analysis. All correlation results are beneath 0.70 . In our analysis, the correlation coefficient ranges from -0.10 to 0.59 . Table 2 recommends that no strong multicollinearity problem would influence the results. Furthermore, the variance inflationary factor (VIF) did not pass 3 , and the highest correlation among the variables also abides by being less than 0.70 . The descriptive statistics and correlation analysis can be found in Table 2 . 
Table 1. Description of variables; CSRR—corporate social responsibility reporting; FP—firm performance; FLCS—firm life cycle stages.

\begin{tabular}{|c|c|c|}
\hline Variable & Abbreviation & Measurement \\
\hline $\begin{array}{l}\text { Corporate social responsibility } \\
\text { Reporting }\end{array}$ & CSRR & $\begin{array}{l}\text { CSR reporting is measured by the CSR index using a dualistic } \\
\text { method: } 1 \text { if an item disclosed, and } 0 \text { if it not. }\end{array}$ \\
\hline Firm performance (Tobin's Q) & TQ & $\begin{array}{c}\text { Firm performance is measured by }\{\text { Total assets market } \\
\text { capitalization - book value of equity - deferred tax } \\
\text { liability)/total assets. }\end{array}$ \\
\hline Firm life cycle (Firm AGE) & FLC & $\begin{array}{l}\text { Age amongst date that firm is established and each year in } \\
\text { the study }\end{array}$ \\
\hline Total sales growth (\%) & TSG & {$[($ Salest - Salest -1$) /($ Salest -1$)] \times 100$} \\
\hline Total assets growth $(\%)$ & TAG & Asset growth of the firm is measured as the change in total assets. \\
\hline Return on assets & ROA & Total assets/firm profit \\
\hline Board Size & BS & Number of directors in the board \\
\hline Firm Size & FS & Total assets, size natural logarithm \\
\hline Independent Director & ID & $\begin{array}{l}\text { Number of independent directors divided by total directors and } \\
\text { multiplied by } 100\end{array}$ \\
\hline Board shares & BS & The proportion of shares held by a firm's board of directors \\
\hline Book-to-Market Ratio & BTMA & Book-to-market ratio of shareholders' equity \\
\hline State-Owned Enterprises & SOE & $\begin{array}{l}\text { Dichotomous variable equal to } 1 \text { if the state or government } \\
\text { controlled firm; otherwise, } 0\end{array}$ \\
\hline Board Meeting & $\mathrm{BM}$ & Number of meetings in one year \\
\hline Financial Leverage & FL & Financial leverage is calculated as total assets divided by total debt. \\
\hline CEO Duality & $\mathrm{CD}$ & CEO and chairman are the same position; otherwise, 0 \\
\hline Firm Growth & FG & The change in a firm's total assets \\
\hline Year and industry dummies & YID & $\begin{array}{l}\text { To control the effect of year and industry, dummies are included to } \\
\text { control specific time and industry effects. }\end{array}$ \\
\hline
\end{tabular}

Table 2. Descriptive statistics and correlation analysis.

\begin{tabular}{|c|c|c|c|c|c|c|c|c|c|c|c|c|c|c|c|c|c|}
\hline Variables & Mean & SD & Min & Max & (1) & (2) & (3) & (4) & (5) & (6) & (7) & (8) & (9) & (10) & (11) & (12) & (13) \\
\hline (1) CSRR & 28.7 & 19.46 & 0 & 90.84 & 1.00 & & & & & & & & & & & & \\
\hline (2) F performance & 2.45 & 1.94 & 0.76 & 33.67 & $-0.10 *$ & 1.00 & & & & & & & & & & & \\
\hline (3) Life Cycle & 2.01 & 0.88 & 0 & 3.25 & $-0.15 *$ & $0.03 *$ & 1.00 & & & & & & & & & & \\
\hline (4) Board size & 9.48 & 2.28 & 4 & 22 & $-0.15 *$ & $0.10^{*}$ & $0.06^{*}$ & 1.00 & & & & & & & & & \\
\hline (5) Firm Size & 23.19 & 1.74 & 18.26 & 30.81 & $-0.43 *$ & $0.34^{*}$ & $0.18^{*}$ & $0.23 *$ & 1.00 & & & & & & & & \\
\hline (6) Ind_Director & 3.49 & 0.83 & 1 & 8 & -0.14 * & $0.13^{*}$ & 0.04 & $0.48^{*}$ & $0.31^{*}$ & 1.00 & & & & & & & \\
\hline (7) B Shares & 19.95 & 1.12 & 17.37 & 26.61 & $-0.28 *$ & $0.33^{*}$ & $0.13 *$ & $0.21^{*}$ & $0.58^{*}$ & $0.30 *$ & 1.00 & & & & & & \\
\hline (8) BTMA & 1.18 & 1.15 & 0.03 & 10.32 & $-0.45^{*}$ & $0.11^{*}$ & $0.13^{*}$ & $0.09 *$ & $0.59 *$ & $0.15 *$ & $0.41 *$ & 1.00 & & & & & \\
\hline (9) SOE & 0.16 & 0.34 & -0.82 & 10.88 & $0.11 *$ & -0.02 & $-0.08^{*}$ & -0.02 & 0.01 & -0.00 & -0.03 & -0.04 & 1.00 & & & & \\
\hline (10) B Meeting & 10.21 & 4.79 & 1 & 57 & $-0.05^{*}$ & $0.10^{*}$ & $0.05^{*}$ & 0.00 & $0.20 *$ & 0.04 & $0.18 *$ & $0.16^{*}$ & $0.11 *$ & 1.00 & & & \\
\hline (11) Fin_Leverage & 0.50 & 0.81 & 0.00 & 1.34 & $-0.41 *$ & $0.09 *$ & $0.22 *$ & $0.11^{*}$ & $0.51^{*}$ & $0.14 *$ & $0.28 *$ & $0.51^{*}$ & -0.01 & $0.22 *$ & 1.00 & & \\
\hline (12) CEO Duality & 0.15 & 0.36 & 1 & 1 & $0.13 *$ & -0.03 & $-0.14^{*}$ & $-0.13^{*}$ & -0.10 & $0.08^{*}$ & -0.09 & $-0.11^{*}$ & $0.08^{*}$ & -0.00 & $-0.11 *$ & 1.00 & \\
\hline (13) Firm Growth & 13.83 & 9.36 & 0 & 28.62 & -0.04 & $0.06^{*}$ & $-0.06^{*}$ & $0.07^{*}$ & 0.26 & $0.08^{*}$ & 0.17 & $0.11 *$ & $0.35 *$ & $0.10^{*}$ & $0.08 *$ & 0.01 & 1.00 \\
\hline
\end{tabular}

Notes: *, significance at the 0.05 level. T-statistics are reported in parentheses. Year and industry dummies are included but not reported here. For a detailed description of variable, see Table 1.

Table 3 shows the OLS regression results when testing $\mathrm{H} 1$ and $\mathrm{H} 2$ and presents the estimations of the coefficients of variables to test the association between CSR reporting and FP with the moderating effects of life cycle stages. Model 1 shows that FP is positive and statistically significant at the $1 \%$ level, with a coefficient value of $t=4.84, p<0.000$. Model 2 shows that the moderating effects of firm life cycle stages are statistically significant and negative at the $1 \%$ level, with a coefficient value of $\mathrm{t}=-3.65, p<0.000$. CSR reporting shows a statistically significant and positive relationship with FP measures. Hence, Hypothesis 1 is accepted according to the results explaining that CSR is enhanced as social responsibility increases. Owners and stakeholders acquire benefits from social activities because their FP improves with CSRR activities. Accordingly, the advantage of investing in social activities 
is that it leads to a positive comeback of the market, make net profits surge, and reinforce the solidity of total financial growth [18].

Table 3. OLS regression using a Farman mode.

\begin{tabular}{|c|c|c|c|}
\hline Variables & Model 1 & Model 2 & Model 3 \\
\hline CSRR & OLS & OLS & OLS \\
\hline FP & $0.065^{* * *}(4.84)$ & $\longrightarrow$ & $0.062^{* * *}(4.52)$ \\
\hline Firm Life Cycle & $\longrightarrow$ & $-0.123^{* * *}(-3.65)$ & $-0.119^{* * *}(-3.54)$ \\
\hline Interaction & $\longrightarrow$ & $\longrightarrow$ & $0.030^{* * *}(3.19)$ \\
\hline Board Size & $-0.085^{* * *}(-3.74)$ & $-0.082 * * *(-3.59)$ & $-0.083^{* * *}(-3.61)$ \\
\hline Firm Size & $-0.878^{* * *}(-14.83)$ & $-0.868^{* * *}(-14.77)$ & $-0.870^{* * *}(-14.63)$ \\
\hline Independ Direct & $0.151 *(2.43)$ & $0.145 *(2.33)$ & $0.147 *(2.35)$ \\
\hline B_share & $0.603^{* * *}(9.96)$ & $0.597^{* * *}(9.85)$ & $0.597^{* * *}(9.84)$ \\
\hline BTMA & $-0.147^{* * *}(-3.95)$ & $-0.154^{* * *}(-4.16)$ & $-0.154^{* * *}(-4.13)$ \\
\hline SOE & $0.542 * * *(5.91)$ & $0.515^{* * *}(5.27)$ & $0.516^{* * *}(5.27)$ \\
\hline Board Meeting & $0.009(1.54)$ & $0.010(1.66)$ & $0.010(1.62)$ \\
\hline Fin_Leverage & $-1.307^{* * *}(-6.51)$ & $-1.215^{* * *}(-5.96)$ & $-1.214^{* * *}(-5.95)$ \\
\hline CEO Duality & $0.248^{* * *}(3.06)$ & $0.229^{* * *}(2.78)$ & $0.228 * *(2.76)$ \\
\hline Firm Growth & $0.011^{* * *}(2.86)$ & $0.011^{* * *}(2.87)$ & $0.011^{* * *}(2.86)$ \\
\hline Constant & $11.568^{* * *}(18.66)$ & $11.599^{* * *}(19.16)$ & $11.624^{* * *}(18.45)$ \\
\hline R-squared & 0.3514 & 0.3491 & 0.3492 \\
\hline
\end{tabular}

Notes: ${ }^{*}, * *$ and ${ }^{* * *}$, significant at $10 \%, 5 \%$, and $1 \%$, respectively. T-statistics are reported in parentheses. Year and industry dummies are included but not reported here. For a detailed description of variable, see Table 1.

Therefore, the connection between CSRR and firm performance was found to be positive. According to [19] and [20], firm size is important to discuss. Model 1 presents a firm size coefficient of $\mathrm{t}=-14.83, p<0.000$, significant at the $1 \%$ level; model 2 presents $\mathrm{t}=$ $-14.77, p<0.000$, also significant; and model 3 presents $t=-14.63, p<0.000$, also significant. Our firm size results vary, and this is not unexpected because negative but significant results show that smaller firms have more growth opportunities than bigger firms. This is because firm size and FP have a true relationship that can be curvilinear [16-18].

For the moderation hypothesis test, the most important variable at this point is the interaction term ( $\mathrm{FP}^{*}$ life cycle stage). The positive coefficient value of $\mathrm{FP}^{*}$ life cycle stage $(t=3.19, p<0.000)$ is statistically significant at the $1 \%$ level, suggesting that, when adjusting for further elements, the average upsurge in organizational performance controlled by CSRR is greater for firms with life cycle stages. Hence, the results also support our second hypothesis 2 that firm life cycle stages have negative effects on the link between CSRR and FP, suggesting that this negative connection is more noticeable for organizations with life cycle stages. To support our conclusion, several studies have found that CSRR and FP have a negative connection with the effects of life cycle stage [16,22] while experiencing moderating effects, as supported by $[20,21,26]$.

\subsection{Robustness Tests}

Alternative Measure of Firm Performance.

We interchanged Tobin's $Q$ with the return on assets (ROA), which is calculated using the net profit divided by the total assets. The results for the alternative measures are reported in Table 4. The coefficient of FP remains significant in model $1(\mathrm{t}=3.61, p<0.000)$. The coefficient of LFCS remains negatively significant in model $2(t=-3.67, p<0.000)$, and the coefficient of $(\mathrm{FP})$ remains positive and significant in model $3(\mathrm{t}=3.55, p<0.000)$. These findings are consistent with our previous findings reported in Table 3. 
Table 4. Robustness checks: alternative measure of firm performance.

\begin{tabular}{|c|c|c|c|}
\hline Variables & Model 1 & Model 2 & Model 3 \\
\hline CSRR & OLS & OLS & OLS \\
\hline ROA & $0.001^{* * *}(3.61)$ & $\longrightarrow$ & $0.008^{* * *}(3.55)$ \\
\hline Firm Life Cycle & $\longrightarrow$ & $-0.125^{* * *}(-3.67)$ & $-0.119^{* *}(-3.56)$ \\
\hline Interaction & $\longrightarrow$ & - & $0.000^{* * *}(3.04) 0.002$ \\
\hline Board Size & $-0.0002(-0.33)$ & $-0.000^{* * *}(-0.65)$ & $-0.000(-0.64)$ \\
\hline Firm Size & $0.024^{* * *}(10.25)$ & $0.024^{* * *}(14.72)$ & $0.025^{* * *}(15.11)$ \\
\hline Independ Direct & $-0.001 *(-0.86)$ & $-0.001 *(-0.78)$ & $-0.001(-0.74)$ \\
\hline B_share & $-0.016^{* * *}(-6.68)$ & $-0.016^{* * *}(-9.79)$ & $-0.017^{* * *}(-9.92)$ \\
\hline BTMA & $-0.012^{* * *}(-12.91)$ & $-0.012^{* * *}(-11.61)$ & $-0.012^{* * *}(-11.91)$ \\
\hline SOE & $0.006^{* * *}(1.13)$ & $0.006 *(2.53)$ & $0.007^{* *}(2.64)$ \\
\hline Board Meeting & $-0.000 *(-2.28)$ & $-0.000(-1.96)$ & $-0.000 *(-1.99)$ \\
\hline Fin_Leverage & $-0.141^{* * *}(-16.02)$ & $-0.142 * * *(-24.93)$ & $-0.141^{* * *}(-24.61)$ \\
\hline CEO Duality & $0.005^{* *}(2.32)$ & $0.005^{* *}(2.36)$ & $0.004 *(2.07)$ \\
\hline Firm Growth & $0.001^{* * *}(11.04)$ & $0.001^{* * *}(13.59)$ & $0.001^{* * *}(13.12)$ \\
\hline Constant & $10.568^{* * *}(17.66)$ & $10.599^{* * *}(17.16)$ & $10.624^{* * *}(17.45)$ \\
\hline R-squared & 0.3585 & 0.3580 & 0.3610 \\
\hline
\end{tabular}

Notes: ${ }^{*}, * *$, and ${ }^{* * *}$, significant at $10 \%, 5 \%$, and $1 \%$, respectively. T-statistics are reported in parentheses. Year and industry dummies are included but not reported here. For a detailed description of variable, see Table 1.

\subsection{Controlling the Endogeneity Issue}

To deal with the endogeneity problem, we used two different methods. First, we used a one-year lag in firm performance in the regression because the performance of the company needs time before it has any influence on the CSRR decisions. Models 1, 2 , and 3 of Table 5 demonstrate the findings of the lagged measures. The outcomes for the lagged measures of the firm performance variables remain consistent with our main results in Table 3. Second, we used two-stage least squares (2SLS) regression to address the endogeneity problem and used a one-year lag in the measure of firm performance as an instrumental variable. Models 5, 6, and 7 of Table 5 show the findings of 2SLS, and our results are, again, the same as with the main findings.

Table 5. Endogeneity tests.

\begin{tabular}{|c|c|c|c|c|c|c|}
\hline \multirow{2}{*}{\begin{tabular}{|c|} 
Models \\
Variables
\end{tabular}} & \multicolumn{3}{|c|}{ Lagged OLS } & \multicolumn{3}{|c|}{2 SLS } \\
\hline & Model 1 & Model 2 & Model 3 & Model 4 & Model 5 & Model 6 \\
\hline CSRR & Full Sample & Full Sample & Full Sample & Full Sample & Full Sample & Full Sample \\
\hline $\mathrm{FP}$ & $0.011^{* * *}(3.00)$ & - & $0.008^{* * *}(3.54)$ & $0.022 * * *(3.39)$ & $\longrightarrow$ & $0.006^{* * *}(3.52)$ \\
\hline Firm Life Cycle & & $\begin{array}{c}-0.131^{* * *} \\
(-3.06) 0.002\end{array}$ & $\begin{array}{c}-0.111^{* *} \\
(-2.03) 0.036\end{array}$ & & $\begin{array}{c}-0.405^{* * *} \\
(-2.81)\end{array}$ & $\begin{array}{c}-0.340^{* *}(2.74) \\
0.009\end{array}$ \\
\hline Interaction & & & $\begin{array}{c}-0.003^{* * *} \\
(3.03) 0.001\end{array}$ & & - & $\begin{array}{c}0.002^{* * *}(3.01) \\
0.002\end{array}$ \\
\hline Board Size & $\begin{array}{c}-0.086^{* * *} \\
(-3.90)\end{array}$ & $\begin{array}{c}-0.082 * * * \\
(-3.71)\end{array}$ & $\begin{array}{c}-0.081^{* * *} \\
(-3.67)\end{array}$ & $\begin{array}{c}-0.092 * * * \\
(-3.64)\end{array}$ & $\begin{array}{c}-0.077^{* * *} \\
(-3.46)\end{array}$ & $\begin{array}{l}-0.092 * \\
(-1.78)\end{array}$ \\
\hline Firm Size & $\begin{array}{l}-0.811^{* * *} \\
(-14.15)\end{array}$ & $\begin{array}{c}-0.794^{* * *} \\
(-13.93)\end{array}$ & $\begin{array}{l}-0.803^{* * *} \\
(-13.95)\end{array}$ & $\begin{array}{c}-0.880 * * * \\
(-6.13)\end{array}$ & $\begin{array}{c}-0.776^{* * *} \\
(-13.41)\end{array}$ & $\begin{array}{c}-0.839 * * * \\
(-5.32)\end{array}$ \\
\hline
\end{tabular}


Table 5. Cont.

\begin{tabular}{|c|c|c|c|c|c|c|}
\hline \multirow{2}{*}{$\begin{array}{c}\text { Models } \\
\text { Variables }\end{array}$} & \multicolumn{3}{|c|}{ Lagged OLS } & \multicolumn{3}{|c|}{$2 \mathrm{SLS}$} \\
\hline & Model 1 & Model 2 & Model 3 & Model 4 & Model 5 & Model 6 \\
\hline Independ Direct & $0.171^{* * *}(2.85)$ & $0.163 * *(2.71)$ & $0.160 * *(2.65)$ & $0.167^{* *}(2.73)$ & $0.156 *(2.58)$ & $0.168 *(1.78)$ \\
\hline B_share & $0.538^{* * *}(9.20)$ & $0.533^{* * *}(9.09)$ & $0.532 * * *(9.08)$ & $0.530^{* * *}(8.68)$ & $0.520 * * *(8.80)$ & $0.513^{* * *}(8.23)$ \\
\hline BTMA & $\begin{array}{c}-0.166^{* * *} \\
(-4.67)\end{array}$ & $\begin{array}{c}-0.172^{* * *} \\
(-4.85)\end{array}$ & $\begin{array}{c}-0.169 * * * \\
(-4.72)\end{array}$ & $\begin{array}{l}-0.142 * \\
(-2.41)\end{array}$ & $\begin{array}{c}-0.180 * * * \\
(-5.0)\end{array}$ & $\begin{array}{c}-0.160 * * \\
(-2.60)\end{array}$ \\
\hline SOE & $0.513^{* * *}(5.64)$ & $0.536^{* * *}(5.74)$ & $0.539 * *(5.78)$ & $0.531 * *(5.41)$ & $0.509^{* * *}(5.38)$ & $0.525^{* * *}(5.06)$ \\
\hline Board Meeting & 0.009 (1.63) & $0.010(1.71)$ & $0.010 *(1.71)$ & $0.007(1.12)$ & $0.010 *(1.70)$ & $0.006(0.57)$ \\
\hline Fin_Leverage & $\begin{array}{c}-1.248^{* * *} \\
(-6.41)\end{array}$ & $\begin{array}{c}-1.182^{* * *} \\
(-5.99)\end{array}$ & $\begin{array}{c}-1.178^{* * *} \\
(-5.97)\end{array}$ & $\begin{array}{c}-1.193^{* * *} \\
(-5.33)\end{array}$ & $\begin{array}{c}-0.992 \text { *** } \\
(-4.51\end{array}$ & $\begin{array}{c}-0.960 * * * \\
(-3.92)\end{array}$ \\
\hline CEO Duality & $0.237^{* * *}(3.02)$ & $0.214^{* *}(2.70)$ & $0.219 * *(2.75)$ & $0.249^{* * *}(3.01)$ & $0.151 *(1.77)$ & $0.154(1.51)$ \\
\hline Firm Growth & $0.013^{* * *}(3.34)$ & $0.011^{* * *}(3.00)$ & $0.011^{* * *}(3.01)$ & $0.012 * * *(3.24)$ & $0.010 * *(2.53)$ & $0.009 *(2.38)$ \\
\hline Constant & $\begin{array}{c}10.915^{* * *} \\
(18.57)\end{array}$ & $\begin{array}{c}10.947^{* * *} \\
(18.93)\end{array}$ & $\begin{array}{c}11.117^{* * *} \\
(18.60)\end{array}$ & $12.071^{* * *}(5.27)$ & $\begin{array}{c}11.293^{* * *} \\
(18.64)\end{array}$ & $12.179^{* * *}(5.11)$ \\
\hline R-squared & 0.3553 & 0.3571 & 0.3574 & 0.3376 & 0.3485 & 0.3310 \\
\hline
\end{tabular}

Notes: $* * *$, and $* * *$, significant at $10 \%, 5 \%$, and $1 \%$, respectively. T-statistics are reported in parentheses. Year and industry dummies are included but not reported here. For a detailed description of variable, see Table 1.

\section{Conclusions}

This paper examined the connection between the CSR Reporting and Firms Performance (FP). By this means, it also examines the channels through which the firm life cycle may moderate CSRR initiatives and FP. Based on a sample of Chinese A-share listed firms covering the 2010-2020 period, we explored the influence of FP on CSR reporting through the lens of the stakeholder, life cycle theory, and legitimacy theories. Evidence indicates that FP has a significant impact on CSR reporting and, specifically, firms with better performance report more on CSR activities than those with lower performance [38]. We document that firm maturity is connected positively with CSRR initiatives [39]. We also document that the life cycle stages of firms moderate the variation in CSRR across the firm's performance [40]. Our results are robust to an alternative proxy measure of positive CSR reporting activity and a firm's performance (ROA) [41] and present the moderation between negative firm life cycle stages and CSR Reporting [42].

Our results remain the same after controlling for the problem of endogeneity. Our results have allegations for the increase in CSR reporting in emerging countries, such as China, with financially solidly performing firms pledging more CSR reporting. With a rise in stakeholder pressure, more firms are obligated to assume CSR activities and reporting. Investigations incline toward understand CSR reporting in diverse settings. CSR reporting encourage shareholders to receive non-financial information beyond the firm's financial statements. For controllers, the level of demonstration and reporting of CSR disclosure serves as a "signal" to execute or variation laws that affect CSR activities and reporting. This research has underlined the governmental impact on CSR reporting of Chinese firms in the present perspective. Our results prove that CSR reporting is a legitimate tool for financially better performing firms in China. This is in spite of the state pressure to accept CSR activities and reporting. The key problem that Chinese firms face currently is misperception. As CSR activities and reporting are in its early stages, Chinese firms are not assured regarding CSR attention. From a legitimacy viewpoint, we suggest that Chinese firms should tolerate stakeholders in addition to the state, such as staff, consumers, broadcasting, and NGOs to regulate the apprehension and development of different Chinese firms to ruminate. Chinese firms must also use CSR reporting to control important parts that need their consideration. In addition, Chinese firms should use CSR reporting as an internal audit instrument to control their CSR plan. 


\section{Limitations}

This study has some limitations. First, we focused on the whole CSR index. A comprehensive research of numerous procedures of CSR and their stakeholder influences can be undertaken in the forthcoming research. Future research should apply particular CSR reporting, such as reporting on the protection of employee and customer interests, reporting on the protection of shareholder interests, environment and sustainability reporting, and other CSR practices. Second, this study is constrained to a firm performance (PF) proxy, such as Tobin's $\mathrm{Q}$ and ROA to measure a firm's financial performance. An upcoming study might relate firm performance (FP) indicators (both market-based performance and accounting-based, e.g., price earnings ratio and stock return) more to explore the connection between firm performance (FP) and CSR reporting.

In addition, firm age presents a U-shaped pattern over firm life cycle stages (FLSC). Both size and firm age are two crucial proxies for firm life cycle stage assessment. When size and age are used as firm life cycle stage proxies, the implication is that companies move monotonically over their firm life cycle stages. Therefore, companies face possible difficulty during the firm life cycle stages, such as product innovations, development into new marketplaces, financial shocks, and structural changes, which can be reasons why companies move across firm life cycle stages (FLCS) non-continuously or reach failure. Thus, a firm that can continue recurring development of capitalization profits from a longer established phase where the reward-risk structure is enhanced.

Author Contributions: Conceptualization, X.L.; data curation, N.J.; formal analysis, N.J.; investigation, A.L.K.; resources, Z.L.; writing original draft preparation, N.J.; writing review and editing, Z.L.; supervision, A.L.K. All authors have read and agreed to the published version of the manuscript.

Funding: This research received no external funding.

Institutional Review Board Statement: Not applicable.

Informed Consent Statement: Not applicable.

Data Availability Statement: Not applicable.

Conflicts of Interest: The authors declare no conflict of interest.

\section{References}

1. Cochran, P.L.; Wood, R.A. Corporate social responsibility and financial performance. Acad. Manag. J. 2018, $27,42-56$.

2. McGuire, J.B.; Sundgren, A.; Schneeweis, T. Corporate social responsibility and firm financial performance. Acad. Manag. J. 2019, 31, 854-872.

3. McWilliams, A.; Siegel, D. Corporate social responsibility and financial performance: Correlation or misspecification? Strateg. Manag. J. 2017, 21, 603-609. [CrossRef]

4. Pino, G.; Amatulli, C.; De Angelis, M.; Peluso, A.M. The influence of corporate social responsibility on consumers' attitudes and intentions toward genetically modified foods: Evidence from Italy. J. Clean. Prod. 2016, 112, 2861-2869. [CrossRef]

5. Withisuphakorn, P.; Jiraporn, P. The effect of firm maturity on corporate social responsibility (CSR): Do older firms invest more in CSR? Appl. Econ. Lett. 2016, 23, 298-301. [CrossRef]

6. Zhu, Q.; Zhang, Q. Evaluating practices and drivers of corporate social responsibility: The Chinese context. J. Clean. Prod. 2018, 100, 315-324. [CrossRef]

7. Kao, E.H.; Yeh, C.-C.; Wang, L.-H.; Fung, H.-G. The relationship between CSR and performance: Evidence in China. Pac. Basin Financ. J. 2018, 51, 155-170. [CrossRef]

8. Gallardo-Vázquez, D.; Sanchez-Hernandez, M.I. Measuring Corporate Social Responsibility for competitive success at a regional level. J. Clean. Prod. 2017, 72, 14-22. [CrossRef]

9. Garriga, E.; Melé, D. Corporate social responsibility theories: Mapping the territory. J. Bus. Ethics 2020, 53, 51-71. [CrossRef]

10. Kurapatskie, B.; Darnall, N. Which corporate sustainability activities are associated with greater financial payoffs? Bus. Strategy Environ. 2019, 22, 49-61. [CrossRef]

11. Margolis, J.D.; Walsh, J.P. Misery loves companies: Rethinking social initiatives by business. Adm. Sci. Q. 2018, 48, 268-305. [CrossRef]

12. Alafi, K.; Hasoneh, A.B. Corporate social responsibility associated with customer satisfaction and financial performance a case study with Housing Banks in Jordan. Int. J. Humanit. Soc. Sci. 2019, 2, 102-115. 
13. Kim, S.-H.; Lee, K.-W. Corporate social responsibility (CSR) in accounting: Review and future direction. Daehan J. Bus. 2020, 26, 2397-2425.

14. Wang, D.H.-M.; Chen, P.-H.; Yu, T.H.-K.; Hsiao, C.-Y. The effects of corporate social responsibility on brand equity and firm performance. J. Bus. Res. 2015, 68, 2232-2236. [CrossRef]

15. Chen, L.; Feldmann, A.; Tang, O. The relationship between disclosures of corporate social performance and financial performance: Evidences from GRI reports in manufacturing industry. Int. J. Prod. Econ. 2016, 170, 445-456. [CrossRef]

16. Mallin, C.; Farag, H.; Ow-Yong, K. Corporate social responsibility and financial performance in Islamic banks. J. Econ. Behav. Organ. 2018, 103, S21-S38. [CrossRef]

17. Basuony, M.; Mohamed, E. Board composition, Ownership Concentration, and Voluntary Internet Disclosure by MSM- Listed Companies. Corp. Board Roles Duties Compos. 2014, 10, 60-70. [CrossRef]

18. Lu, W.; Chau, K.; Wang, H.; Pan, W. A decade's debate on the nexus between corporate social and corporate financial performance: A critical review of empirical studies 2002-2011. J. Clean. Prod. 2017, 79, 195-206. [CrossRef]

19. Saeidi, S.P.; Sofian, S.; Saeidi, P.; Saeidi, S.P.; Saaeidi, S.A. How does corporate social responsibility contribute to firm financial performance? The mediating role of competitive advantage, reputation, and customer satisfaction. J. Bus. Res. 2019, 68, 341-350. [CrossRef]

20. Russo, A.; Perrini, F. Investigating Stakeholder Theory and Social Capital: CSR in Large Firms and SMEs. J. Bus. Ethics 2010, 91, 207-221. [CrossRef]

21. Elsayed, K.; Paton, D. The impact of financial performance on environmental policy: Does firm life cycle matter? Bus. Strategy Environ. 2019, 18, 397-413. [CrossRef]

22. Habib, A.; Hasan, M.M. Firm life cycle, corporate risk-taking and investor sentiment. Account. Financ. 2017, 57, 465-497. [CrossRef]

23. Pattanaik, A.; Sengupta, R. Business Cycle Effect on Leverage: A Study of Indian Non-Financial Firms; Indira Gandhi Institute of Development Research: Mumbai, India, 2018.

24. Stjepanović, S.; Tomić, D.; Škare, M. A new approach to measuring green GDP: A cross-country analysis. Entrep. Sustain. Issues 2017, 4, 574-590. [CrossRef]

25. Ahmed, K.; Jinan, M. The association between research and development expenditure and firm performance: Testing a life cycle hypothesis. Int. J. Account. Audit. Perform. Eval. 2016, 7, 267-286. [CrossRef]

26. Al-Hadi, A.; Chatterjee, B.; Yaftian, A.; Taylor, G.; Monzur Hasan, M. Corporate social responsibility performance, financial distress and firm life cycle: Evidence from Australia. Account. Financ. 2017, 59, 961-989. [CrossRef]

27. DesJardins, J.R.; Diedrich, E. Learning what it really costs: Teaching business ethics with life-cycle case studies. J. Bus. Ethics 2019, 48, 33-42. [CrossRef]

28. Sebastian, A.; Malte, B. Understanding the influence of corporate social responsibility on corporate identical performance link. Strateg. Manag. J. 2010, 18, 303-319.

29. Diebecker, J.; Rose, C.; Sommer, F. Corporate Sustainability Performance Over the Firm Life Cycle: Levels, Determinants, and the Impact on Accounting Performance. Determinants and the Impact on Accounting Performance. 2017. Available online: https: / / ssrn.com/abstract=3084601 (accessed on 8 December 2017).

30. Francesco, P.; Russo, A.; Antonio, T. CSR strategies of SMEs and large firms: Evidence from Italy. J. Bus. Ethics 2007, 74, 285-300.34.

31. Teoh, S.H.; Welch, I.; Wazzan, C.P. The effect of socially activist investment policies on the financial markets: Evidence from the South African boycott. J. Bus. 2019, 72, 35-89. [CrossRef]

32. Inoue, Y.; Lee, S. Effects of different dimensions of corporate social responsibility on corporate financial performance in tourismrelated industries. Tour. Manag. 2011, 32, 790-804. [CrossRef]

33. Bird, R.G.; Hall, A.D.; Momente, F.; Reggiani, F. What Corporate Social Responsibility Activities are Valued by the Market? J. Bus. Ethics 2007, 76, 189-206. [CrossRef]

34. Valentine, S.; Fleischman, G. (Ethics Programs, Perceived Corporate Social Responsibility and Job Satisfaction. J. Bus. Ethics 2008, 77, 159-172. [CrossRef]

35. Posnikoff, J.F. Disinvestment from South Africa: They did well by doing good. Contemp. Econ. Policy 2020, 15, 76-86. [CrossRef]

36. Worrell, D.L.; Davidson, W.N., III.; Sharma, V.M. Layoff announcements and stockholder wealth. Acad. Manag. J. 2018, 34, 662-678. [CrossRef]

37. Wright, P.; Ferris, S.P. Agency conflict and corporate strategy: The effect of divestment on corporate value. Strateg. Manag. J. 2019, 18, 77-83. [CrossRef]

38. Peloza, J.; Papania, L. The missing link between corporate social responsibility and financial performance: Stakeholder salience and identification. Corp. Reput. Rev. 2008, 11, 169-181. [CrossRef]

39. Moore, G. Corporate social and financial performance: An investigation in the U.K. supermarket industry. J. Bus. Ethics 2001, 34, 299-315. [CrossRef]

40. Amin, H.; Mohamed, E. Internet Financial Reporting, Quality of Information and Auditor's Responsibility in Egypt. Int. J. Econ. Account. 2012, 3, 276-294. [CrossRef]

41. Park, J.E. Exploring the Effect of Corporate Social Responsibility on Firm Performance: Antecedent Mediator and Moderators. Ph.D. Thesis, School of Saint Louis University, St. Louis, MO, USA, 2010.

42. Aupperle, K.E.; Carroll, A.B.; Hatfield, J.D. An empirical examination of the relationship between corporate social responsibility and profitability. Acad. Manag. J. 2019, 28, 446-463. 